\title{
Dam tailwaters compound the effects of reservoirs on the longitudinal transport of organic carbon in an arid river
}

\author{
A. J. Ulseth ${ }^{1,2, a}$ and R. O. Hall Jr. ${ }^{2}$ \\ ${ }^{1}$ Program in Ecology, University of Wyoming, Laramie, Wyoming, USA \\ ${ }^{2}$ Department of Zoology and Physiology, University of Wyoming, Laramie, Wyoming, USA \\ anow at: École Polytechniqe Fédérale de Lausanne, Lausanne, Switzerland
}

Correspondence to: A. J. Ulseth (amber.ulseth@gmail.com)

Received: 3 April 2015 - Published in Biogeosciences Discuss.: 24 April 2015

Accepted: 8 July 2015 - Published: 28 July 2015

\begin{abstract}
Reservoirs on rivers can disrupt organic carbon (OC) transport and transformation, but less is known how river reaches directly below dams contribute to OC processing. We compared how reservoirs and their associated tailwaters affected $\mathrm{OC}$ quantity and quality by calculating particulate OC (POC) and dissolved OC (DOC) fluxes, and measuring composition and bioavailability of DOC. We sampled the Yampa River near Maybell, Colorado, USA, and the Green River above and below Fontenelle and Flaming Gorge reservoirs as well as their respective tailwaters from early snowmelt to base flow hydrological conditions. In unregulated reaches (Yampa River, Green River above Fontenelle reservoir), DOC and POC concentrations increased with snowmelt discharge. POC and DOC concentrations also increased with stream discharge below Fontenelle reservoir, but there was no relationship between DOC and stream flow below Flaming Gorge reservoir. The annual load of POC was 3-fold lower below Fontenelle Reservoir and nearly 7-fold lower below Flaming Gorge reservoir, compared to their respective upstream sampling sites. DOC exported to downstream reaches from both reservoirs was less bioavailable, as measured with bioassays, than DOC upriver of the reservoirs. Lastly, tailwater reaches below the reservoirs generated $\mathrm{OC}$, exporting potentially $1.6-2.2 \mathrm{~g} \mathrm{C} \mathrm{m}^{-2} \mathrm{~d}^{-1}$ of $\mathrm{OC}$ to downstream ecosystems. Therefore, the effect of impounding rivers on $\mathrm{C}$ fluxes is greater than the impact of the reservoirs alone given the additive effect of tailwater reaches below dams, which may produce and export comparable amounts of likely autochthonous carbon to downstream reaches.
\end{abstract}

\section{Introduction}

Unregulated streams and rivers compose a continuous ecosystem where a gradient of physical processes drive biological processes from headwaters to the river deltas (Vannote et al., 1980). Along this continuum, rivers receive terrestrial organic carbon (OC) and export it to the ocean (Cole et al., 2007). The amount of OC that enters the oceans, however, is only a fraction of the estimated input from the terrestrial landscape (Aufdenkampe et al., 2011). A larger fraction of OC entering rivers and streams is believed to be stored and mineralized to $\mathrm{CO}_{2}$ within these ecosystems (Cole et al., 2007; Battin et al., 2009; Aufdenkampe et al., 2011).

Flow regulation by damming has converted most rivers into a series of lotic and lentic reaches (Ward and Stanford, 1983; Benke, 1990), affecting OC cycling and transport (Ward and Stanford, 1983; Miller, 2012; Stackpoole et al., 2014). Reservoirs on rivers may trap particulate OC (POC) (Friedl and Wüest, 2002; Downing et al., 2008; Tranvik et al., 2009) and transform and produce dissolved OC (DOC) (Mash et al., 2004; Knoll et al., 2013). Increased water residence time (Vörösmarty et al., 1997; Sabo et al., 2010) allows for OC to be respired, incorporated into microbial production, or buried while production of autochthonous or microbial DOC increases (Mash et al., 2004; Knoll et al., 2013). This autochthonous DOC can be more bioavailable than terrestrial sources (del Giorgio and Davis, 2003); therefore increasing autochthonous production within these ecosystems potentially increases the bioavailability of DOC, although there is little understanding of the bioavailability 
of DOC exported downstream of reservoirs. Compositional changes in DOC may or may not occur as well. For instance, DOC composition did not change from upstream to downstream of reservoirs in boreal-forested rivers in northern Ontario where catchment characteristics had a stronger influence compared to the presence of impoundments (Nadon et al., 2014). Therefore coupling DOC bioavailability and composition is needed to understand the transformative processes reservoirs can have on DOC and ultimately riverine $\mathrm{C}$ cycling. In regards to DOC concentration, various studies have found that reservoirs may increase (Parks and Baker, 1997), decrease (Miller, 2012; Knoll et al., 2013), or not alter DOC concentrations to downstream ecosystems (Parks and Baker, 1997; Nadon et al., 2014). Prior work has shown DOC fluxes increased longitudinally in the upper basin of the Colorado River, but then decreased with the presence of large reservoirs in the lower basin (Miller, 2012; Stackpoole et al., 2014). Conversely DOC fluxes increased in the lower Missouri River despite the presence of large reservoirs (Stackpoole et al., 2014). These studies have given insight into longitudinal OC fluxes in light of flow regulation by dams, but fluxes in combination with bioavailability and composition of DOC are less understood.

Tailwater reaches can be found directly downstream of all dams (Ward and Stanford, 1983), yet coupled reservoir and tailwater OC fluxes are unclear within the context of riverine OC budgets. Within the scope of this research, we define tailwater reaches as the stream reach directly downstream of dams, which have no tributary input. These tailwater ecosystems physically and biologically differ from their upstream or pre-dam counterparts (Ward and Stanford, 1983), which may affect DOC and POC dynamics. In these tailwater reaches, sediment transport is lower and bed sediment is more stable than upstream of the reservoir (Schmidt and Wilcock, 2008). These highly altered physical processes result in increased primary production in tailwaters relative to the unaltered or pre-dam river (Davis et al., 2011). Such high production can increase transported POC and DOC (Webster et al., 1979; Perry and Perry, 1991; Lieberman and Burke, 1993; Benenati et al., 2001). Tailwater POC may consist of sloughed algae from production within the river reach (Webster et al., 1979; Perry and Perry, 1991). Algae in tailwaters may increase DOC concentration via exudation (Baines and Pace, 1991; Bertilsson and Jones, 2003). For example, autochthonous DOC flux was correlated with gross primary production in the tailwater of Glen Canyon Dam on the Colorado River and may equate to $7-91 \%$ of gross primary production in the tailwater (Ulseth, 2012). Tailwater ecosystems produce algal OC, which is exported (Perry and Perry, 1991; Lieberman and Burke, 1993), transformed, buried, or consumed. This source of autochthonous, likely more labile C (del Giorgio and Davis, 2003), may result in increased bioavailability of DOC, which could impact riverine $\mathrm{C}$ cycling, but the extent of bioavailability variability in relation to dams and their tailwaters is unknown.
We studied a series of reaches on the Green and Yampa rivers located in the upper basin of the Colorado River, USA, to quantify the role of hydrological regulation on OC quantity and quality. Within this objective, we asked the following questions: (1) how do OC concentration, fluxes, and DOC composition and bioavailability vary temporally in hydrologically regulated reaches compared to free-flowing rivers? (2) How does the bioavailability and composition of DOC vary longitudinally in a river altered by reservoir-tailwater ecosystems? We addressed these questions by quantifying POC and DOC concentration and DOC composition and bioavailability in regulated and unregulated river reaches in the upper Colorado River basin. We sampled from the onset of snowmelt, where we expected transport processes to dominate, and during base flow river conditions where we expected within ecosystem production to drive OC quality and transport.

\section{Methods}

\subsection{Study site}

The Colorado River basin is heavily regulated (Nilsson et al., 2005), making it an opportune river basin to study DOC dynamics in impounded rivers. We selected sampling sites to capture OC processes of non-regulated reaches, above and below reservoirs, and also to capture tailwater OC dynamics. In total, we selected seven sites on the Green and Yampa rivers located in the upper basin of the Colorado River (Fig. 1). Two sites served as unregulated reaches: the Green River above Fontenelle reservoir near La Barge, Wyoming (Fig. 1, A), and the Yampa River near Maybell, Colorado (Fig. 1, G). To capture potential longitudinal changes in OC transport and DOC composition and quality, we continued our sampling downstream starting above Fontenelle reservoir. Fontenelle reservoir had a mean water capacity of $0.26 \mathrm{~km}^{3}$ and a mean water residence time of 0.13 years for 2011 (Appendix Table A1). We sampled below Fontenelle dam at two locations: directly below the dam (Fig. 1, B) and another site $39.6 \mathrm{~km}$ downriver to measure the OC dynamics in the tailwater (referred to as Fontenelle tailwater, Fig. 1, C). Further downstream, we sampled above Flaming Gorge reservoir (Fig. 1, D). During 2011, Flaming Gorge reservoir had a mean volume of $4.08 \mathrm{~km}^{3}$ and a mean residence time of 1.61 years (Table A1). We sampled at two locations below Flaming Gorge dam, immediately below the dam (Fig. 1, E) and $25.7 \mathrm{~km}$ further downriver to capture tailwater effects on OC dynamics (referred to as Flaming Gorge tailwater, Fig. 1, F). Our sampling sites were located at US Geological Survey gaging stations, except for tailwater sites. For tailwater sites we assumed no change in discharge over these short distances from the dams.

We sampled from the onset of snowmelt to base flow in 1 year to compare processes during runoff and base flow in 


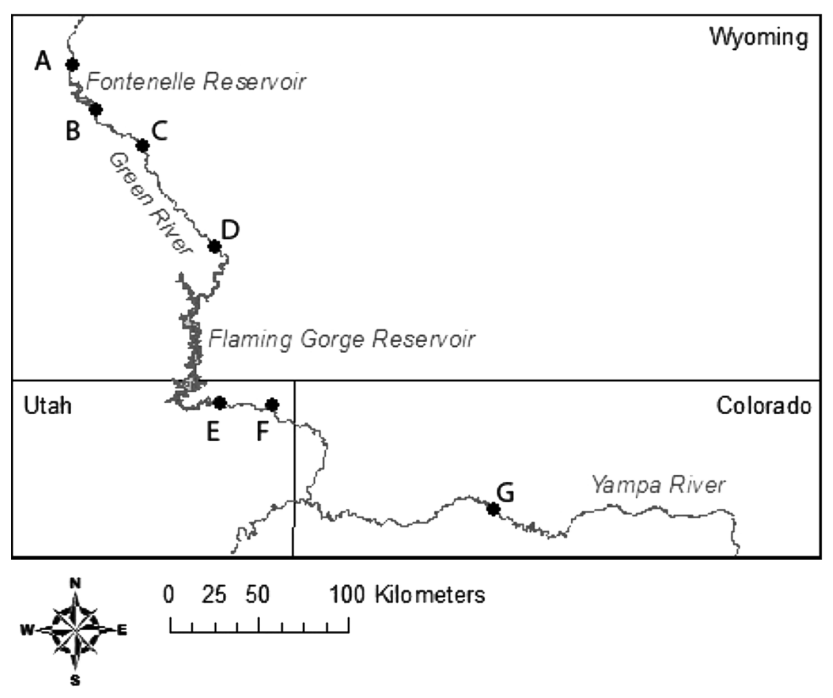

Figure 1. Map of Fontenelle and Flaming Gorge reservoirs located on the Green River in Wyoming and Utah and the Yampa River located in Colorado. The points along the rivers designate the locations from where we collected water from April to October 2011. Two sites located on unregulated river reaches: the Green River above Fontenelle reservoir (A) (USGS gaging station 09209400) and the Yampa River (G) (USGS gaging station 09251000). We also sampled directly below Fontenelle dam (B) (USGS gaging station 09211200) and $39.6 \mathrm{~km}$ down river for the Fontenelle tailwater (C). We sampled above Flaming Gorge reservoir (D) (USGS gaging station 09217000) and directly below Flaming Gorge dam (E) (USGS gaging station 09234500) and $25.7 \mathrm{~km}$ further downstream for Flaming Gorge tailwater (F).

these snowmelt-driven rivers. We sampled at the beginning of snowmelt in late April 2011 and continued into October of 2011 every $2-7$ weeks for a total of eight sampling periods. In 2011, the Yampa and Green rivers had high sustained flows into late July (Fig. 2). All sampling sites were accessible by car, and collection of samples took place over a 2-day period for each round of sampling.

\subsection{Sample collection}

We collected samples to quantify DOC concentration, composition, and bioavailability as well as particulates for POC. We used acid-washed polyethylene Cubitainers to collect water from each sampling site. We immediately placed the collected water on ice and filtered it within $8 \mathrm{~h}$ of collection. We used a pre-rinsed Supor capsule filter $(0.2 \mu \mathrm{m}$ capsule filter; Pall SUPOR AcroPak 200) to filter approximately $4 \mathrm{~L}$ of water from each site for the bioassay experiments described below. From the remaining water, we collected samples for absorbance spectroscopy measurements and DOC concentration. The water samples were filtered into acid-washed, precombusted $40 \mathrm{~mL}$ amber glass vials. Four replicates were immediately acidified with $400 \mu \mathrm{L}$ of $2 \mathrm{~N} \mathrm{HCl}$ for later DOC analysis, and four other replicates were used for spectral
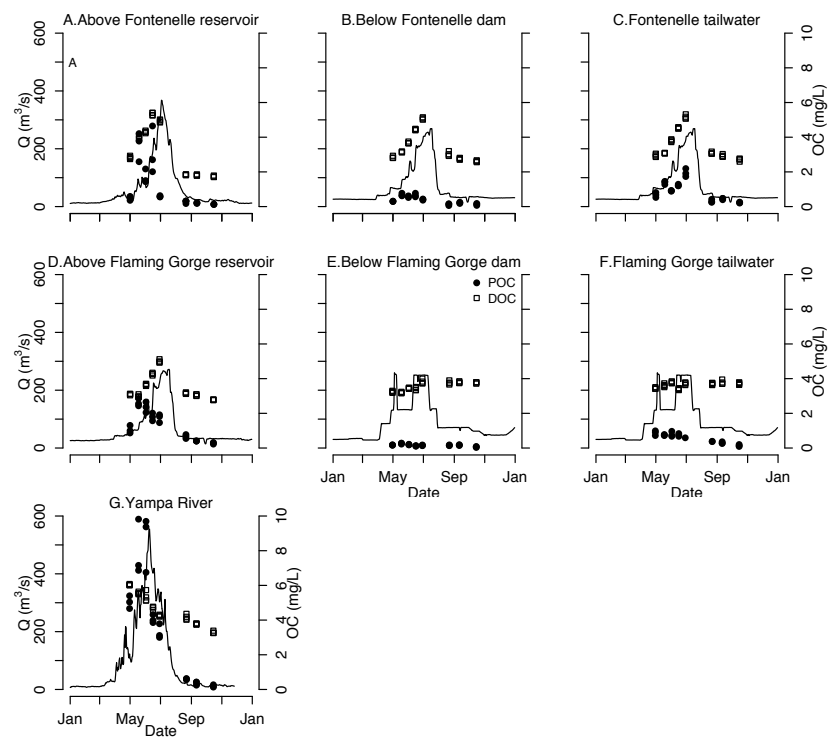

Figure 2. Discharge (line, $\mathrm{Q} \mathrm{m}^{3} \mathrm{~s}^{-1}$ ) plotted for 2011 along with particulate organic carbon (POC; replicate samples plotted) and dissolved organic carbon (DOC; replicate samples plotted) concentrations from sampling sites located on the Green and Yampa rivers. Letters $A-G$ preceding the site names correspond to sites $A-G$ in Fig. 1.

measurements. All DOC samples were kept cold and dark until analyses. We analyzed DOC samples on a Shimadzu TOC 5000A in Laramie, Wyoming. Individual samples were run a minimum of three times to estimate analytical precision. The coefficient of variation for replicate runs of the same sample was $<2 \%$.

\subsection{DOC composition}

We used spectrophotometric absorbance to evaluate DOC chemical composition. We used a scanning spectrophotometer to measure the absorbance of DOC from 200 to $600 \mathrm{~nm}$ on a Beckman DU spectrophotometer. We scanned the DOC samples using a $5 \mathrm{~cm}$ quartz cuvette and used deionized water as the blank. To characterize the structure of DOC, we used the absorbance measured at $254 \mathrm{~nm}$, normalized by the DOC concentration, to calculate specific ultraviolet absorption, otherwise referred to as $\mathrm{SUVA}_{254}\left(\mathrm{~L} \mathrm{mg} \mathrm{C}^{-1} \mathrm{~m}^{-1}\right)$. SUVA $_{254}$ indicates the aromaticity of the $\mathrm{C}$ compounds and is positively correlated with double $\mathrm{C}$ bonds and molecular weight, with higher values indicating more aromaticity of the DOC compounds (Chin et al., 1994; Weishaar et al., 2003). Additionally, we calculated the spectral slope ratio $\left(S_{\mathrm{R}}\right) . S_{\mathrm{R}}$ is the ratio of the spectral slopes $\left(S_{275-295}: S_{350-400}\right)$ at wavelength regions of 275-295 and 350-400 (Helms et al., 2008). $S_{\mathrm{R}}$ is inversely correlated with DOC molecular weight and has been shown to shift in response to DOC photo alteration (Helms et al., 2008). By using SUVA 254 and $S_{R}$ we expected higher $\mathrm{SUVA}_{254}$ values and lower $S_{\mathrm{R}}$ values for more aro- 
matic, higher-molecular-weight DOC, and lower SUVA 254 and higher $S_{\mathrm{R}}$ for less aromatic and lower-molecular-weight DOC.

\subsection{Bioassay experiments to estimate bioavailability of DOC}

Bioassay experiments, where we measured the decline in DOC over time, represent the potential bioavailability of DOC to the microbial assemblage (del Giorgio and Davis, 2003). For each bioassay experiment, we added $1 \mathrm{~L}$ of $0.2 \mu \mathrm{m}$ filtered river water to an acid-washed, pre-combusted glass jar. Then, we inoculated the filtered river water with $10 \mathrm{~mL}$ of $0.7 \mu \mathrm{m}$ filtered water (pre-combusted glass fiber filter; Whatman GF/F, similar pore size to Bano et al., 1997). We chose $0.7 \mu \mathrm{m}$ filtered water as inoculum to exclude any large particulates but include bacteria that would likely not pass through the $0.2 \mu \mathrm{m}$ filters. We inoculated deionized water with $10 \mathrm{~mL}$ of $0.7 \mu \mathrm{m}$ filtered water as a control. We ran the bioassays in triplicate, with one control per site and date. We incubated all bioassay experiments in the dark throughout the experiment. We collected DOC samples from the bioassay jars every few days for 28 days and then preserved and analyzed as described above. The decline in DOC concentration over time was fit to a first-order exponential decay model (Guillemette and del Giorgio, 2011) such that

$\operatorname{lnDOC}_{\text {total }}=\operatorname{lnDOC} C_{\text {initial }}-k t$,

where $\operatorname{lnDOC}_{\text {total }}$ is the natural $\log$-transformed total DOC concentration $\left(\mathrm{mg} \mathrm{L}^{-1}\right), \operatorname{lnDOC}_{\text {initial }}$ is the natural $\log$ transformed initial concentration of DOC $\left(\mathrm{mg} \mathrm{L}^{-1}\right), k$ is the decay rate $\left(\mathrm{d}^{-1}\right)$, and $t$ is incubation time $(d)$. We used the $\mathrm{lm}$ function (linear model) in R ( $\mathrm{R}$ Development Core Team, 2015) to solve for $k$ by regressing the natural $\log$ of DOC concentration by day.

\subsection{Particulate organic carbon}

We filtered $0.2-5 \mathrm{~L}$ of river water, depending on the site and amount of sample visibly retained on the filter, through precombusted glass fiber filters to estimate POC (pre-combusted glass fiber filter; Whatman GF/F). Triplicate samples were dried at $60^{\circ} \mathrm{C}$, weighed for dry mass, and combusted at $500{ }^{\circ} \mathrm{C}$. Following combustion, we re-wetted the filters to account for potential clay dehydration, re-dried, and weighed again. The ash-free dry mass (AFDM, $\mathrm{mg} \mathrm{L}^{-1}$ ) of the particulate samples was calculated as the difference in the dry mass (mg) and combusted mass (mg) divided by the volume filtered (L). To estimate POC, we assumed that $45 \%$ of the AFDM was OC (Whittaker and Likens, 1973).

\subsection{Statistical analyses}

To address longitudinal changes in OC transport, we compared the mean POC and DOC concentrations, $\mathrm{SUVA}_{254}, S_{\mathrm{R}}$, and bioavailability as $k\left(\mathrm{~d}^{-1}\right)$ at each site along the Green River with the closest upstream site. We used a paired $t$ test to evaluate whether the mean OC concentrations, spectral data, and bioavailability statistically differed between sites in relation to upstream or downstream of Fontenelle or Flaming Gorge reservoirs and their respective tailwaters (Dalgaard, 2008). We used R (R Development Core Team, 2015) to conduct all statistical analyses.

\subsection{Fluxes of DOC and POC}

We calculated the daily fluxes and annual loads of DOC and POC for each sampling site. Daily fluxes of DOC and POC were calculated as

Flux $_{\mathrm{d}}=Q_{\mathrm{d}} \times[\mathrm{OC}]_{\mathrm{d}}$,

where Flux ${ }_{\mathrm{d}}$ was the daily DOC or POC flux $\left(\mathrm{g} \mathrm{d}^{-1}\right), Q_{\mathrm{d}}$ $\left(\mathrm{m}^{3} \mathrm{~d}^{-1}\right)$ was the mean discharge of day $d$, and $[\mathrm{OC}]_{\mathrm{d}}$ was the mean concentration $\left(\mathrm{g} \mathrm{m}^{-3}\right)$ of either DOC or POC for day $d$. We developed a rating curve for each sampling site relating [OC] to $Q$ using our eight sampling points to estimate $[\mathrm{OC}]_{\mathrm{d}}$ for the 2011 calendar year,

$\ln [\mathrm{OC}]=\beta_{0}+\beta_{1} \ln Q+\beta_{2} \ln Q^{2}$,

where [OC] is POC or DOC concentration; $\beta_{0}, \beta_{1}$, and $\beta_{2}$ are the model coefficients; and $Q$ is discharge $\left(\mathrm{m}^{3} \mathrm{~s}^{-1}\right)$ (similar to Stackpoole et al., 2014). Equation (3) was parameterized for each sampling site (using $\mathrm{lm}$ function in R; R Development Core Team, 2015) to predict daily POC and DOC concentrations based on daily $Q$, except for sites located below Flaming Gorge dam and its respective tailwater where there was no statistical relationship between DOC concentration and $Q$ (Table 1). For these sites, we used the mean of measured DOC concentrations for $[\mathrm{OC}]_{\mathrm{d}}$. All linear models met the assumption of linear regression and given postanalyses diagnostics (Dalgaard, 2008), the models were appropriate given the data. We used linear regression ( $\mathrm{lm}$ function in R; R Development Core Team, 2015) to compare predicted Flux $x_{d}$ to observed Flux $x_{d}$ to further quantify beyond model fit if Eq. (3) was appropriate for predicting $[\mathrm{OC}]_{\mathrm{d}}$ based on $Q$ for the subsequent Flux $\mathrm{d}_{\mathrm{d}}$ calculations. The estimated Flux $_{\mathrm{d}}$ from predicting daily $[\mathrm{OC}]_{\mathrm{d}}$ from Eq. (3) (and using the mean DOC concentrations for sites located below Flaming Gorge dam) was similar to the Flux $_{\mathrm{d}}$ estimates from measured $[\mathrm{OC}]_{\mathrm{d}}$ (Table 2), and therefore we were confident in extrapolating daily Flux $_{\mathrm{d}}$ from predicted $[\mathrm{OC}]_{\mathrm{d}}$ and $Q_{\mathrm{d}}$ for the calendar year of 2011. These daily fluxes were then summed to estimate the 2011 annual loads for DOC and POC for each sampling site. Furthermore, we estimated the potential variation of these annual loads for 2011. We used the $95 \%$ confidence interval of the predicted $[\mathrm{OC}]_{\mathrm{d}}$ from Eq. (3) to re-parameterize the equation in order to predict the $95 \%$ confidence interval for daily DOC and POC concentrations for each site. These predicted lower and upper bound $[\mathrm{OC}]_{\mathrm{d}}$ 
Table 1. A regression model to estimate daily organic carbon concentrations [OC] from mean discharge $(Q), \ln [\mathrm{OC}]=\beta_{0}+\beta_{1} \ln [Q]+\beta_{2}$ $\ln [Q]^{2}$, was fit for each sampling site in order to estimate annual [OC] loads. POC refers to particulate organic carbon and DOC is dissolved organic carbon. $\beta_{0}, \beta_{1}$, and $\beta_{2}$ are the model coefficients for each sampling site. $P$ value and $r^{2}$ are selected corresponding model statistics at each site. Letters $A-G$ preceding the site names correspond to sites $A-G$ in Fig. 1.

\begin{tabular}{lrrrrrrrrrr}
\hline & \multicolumn{4}{c}{ POC } & \multicolumn{4}{c}{ DOC } \\
\cline { 2 - 11 } Site & $\beta_{0}$ & $\beta_{1}$ & $\beta_{2}$ & $P$ value & $r^{2}$ & $\beta_{0}$ & $\beta_{1}$ & $\beta_{2}$ & $P$ value & $r^{2}$ \\
\hline A: Above Fontenelle reservoir & -22.0 & 9.8 & -1.0 & 0.02 & 0.79 & -2.8 & 1.5 & -0.1 & 0.01 & 0.82 \\
B: Below Fontenelle dam & -14.6 & 5.5 & -0.5 & 0.05 & 0.69 & 2.6 & -1.0 & 0.1 & 0.00 & 0.96 \\
C: Fontenelle tailwater & -6.9 & 2.1 & -0.1 & 0.01 & 0.82 & 3.1 & -1.2 & 0.2 & 0.00 & 0.94 \\
D: Above Flaming Gorge reservoir & -25.3 & 10.9 & -1.1 & 0.00 & 0.90 & 3.0 & -1.1 & 0.2 & 0.00 & 0.95 \\
E: Below Flaming Gorge dam & -31.5 & 12.2 & -1.2 & 0.05 & 0.70 & $\mathrm{n} / \mathrm{a}^{*}$ & $\mathrm{n} / \mathrm{a}^{*}$ & $\mathrm{n} / \mathrm{a}^{*}$ & $\mathrm{n} / \mathrm{a}^{*}$ & $\mathrm{n} / \mathrm{a}^{*}$ \\
F: Flaming Gorge tailwater & -41.5 & 16.3 & -1.6 & 0.00 & 0.95 & $\mathrm{n} / \mathrm{a}^{*}$ & $\mathrm{n} / \mathrm{a}^{*}$ & $\mathrm{n} / \mathrm{a}^{*}$ & $\mathrm{n} / \mathrm{a}^{*}$ & $\mathrm{n} / \mathrm{a}^{*}$ \\
G: Yampa River & -9.4 & 3.9 & -0.3 & 0.00 & 0.95 & -0.8 & 1.1 & -0.1 & 0.02 & 0.79 \\
\hline
\end{tabular}

* Not applicable (n/a) as there was no statistical relationship between DOC concentration and $Q$; therefore mean measured DOC concentrations were used to estimate daily fluxes and to calculate annual DOC for 2011.

Table 2. Select model statistics from linear regression ( $\mathrm{lm}$ in R; R Development Core Team, 2015) models to compare predicted organic carbon fluxes to observed particulate organic carbon (POC) and dissolved organic carbon (DOC) fluxes $\left(\right.$ Flux $_{d}$, $\left.\mathrm{td}^{-1}\right)$ for each sampling site. Predicted organic carbon fluxes were calculated from estimated daily organic carbon (POC or DOC) concentrations ([OC]) and discharge $(Q)$. Linear regression models were used to predict $[\mathrm{OC}]$ where $\ln [\mathrm{OC}]=\beta_{0}+\beta_{1} \ln [Q]+\beta_{2} \ln [Q]^{2}$, except for sites below Flaming Gorge dam where there was no statistical relationship between DOC and $Q$. Average measured DOC and discharge were used to estimate daily DOC fluxes for sites below Flaming Gorge dam. Observed OC fluxes were calculated multiplying the mean measured [OC] and corresponding mean daily $Q$. Letters $\mathrm{A}-\mathrm{G}$ preceding the site names correspond to sites A-G in Fig. 1.

\begin{tabular}{|c|c|c|c|c|c|c|c|c|}
\hline \multirow[b]{2}{*}{ Site } & \multicolumn{4}{|c|}{ POC } & \multicolumn{4}{|c|}{ DOC } \\
\hline & intercept & slope & slope SE & $r^{2}$ & intercept & slope & slope SE & $r^{2}$ \\
\hline A: Above Fontenelle reservoir & 2.94 & 0.59 & 0.11 & 0.82 & -1.19 & 1.04 & 0.04 & 0.99 \\
\hline B: Below Fontenelle dam & 0.04 & 0.95 & 0.14 & 0.89 & -0.21 & 1.01 & 0.01 & 1.00 \\
\hline C: Fontenelle tailwater & 0.19 & 0.97 & 0.07 & 0.97 & -0.28 & 1.01 & 0.02 & 1.00 \\
\hline D: Above Flaming Gorge reservoir & 0.41 & 0.95 & 0.12 & 0.92 & -0.27 & 1.01 & 0.01 & 1.00 \\
\hline E: Below Flaming Gorge dam & 0.07 & 0.96 & 0.12 & 0.92 & 0.68 & 0.98 & 0.04 & 0.99 \\
\hline F: Flaming Gorge tailwater & 0.29 & 0.96 & 0.08 & 0.96 & 0.41 & 0.99 & 0.04 & 0.99 \\
\hline G: Yampa River & 22.69 & 0.70 & 0.16 & 0.76 & 2.45 & 0.97 & 0.06 & 0.97 \\
\hline
\end{tabular}

were then summed as described above to estimate the 2011 annual loads for both DOC and POC for each site. As for the sampling site below Flaming Gorge dam and its respective tailwater site, we used the lower and upper bound of the $95 \%$ confidence interval of the measured mean DOC concentration, as there was no linear relationship with DOC concentration and $Q$ at these sites.

\section{Results}

\subsection{Organic carbon concentrations and transport}

Longitudinal OC concentrations and the subsequent OC load for 2011 fluctuated in the presence of reservoir-tailwater ecosystems along the Green River (Table 3). POC concentrations were lower below both Fontenelle and Flaming Gorge dams compared to upstream of the reservoirs (Fig. 2). POC concentrations averaged $1.2 \mathrm{mg} \mathrm{L}^{-1}$ above Fontenelle reser- voir, compared to $0.4 \mathrm{mg} \mathrm{L}^{-1}$ below the dam (paired $t$ test, $p=0.002)$. Lower concentrations of POC directly below Fontenelle dam translated to an annual POC load that was potentially 3-fold lower compared to upstream of the reservoir, although the $95 \%$ confidence intervals of the annual loads overlapped, indicating the high variability in our annual load estimates (Table 3). POC concentrations (Fig. 2) and subsequent daily OC loads (Table 3) above Fontenelle reservoir also had the most temporal variability, similar to the Yampa River, compared to the other sampling sites along the Green River. POC concentrations above Flaming Gorge reservoir averaged $1.4 \mathrm{mg} \mathrm{L}^{-1}$ compared to directly below Flaming Gorge dam, which averaged $0.2 \mathrm{mg} \mathrm{L}^{-1}$ (paired $t$ test, $p<0.0001)$. The annual POC load for 2011 was reduced nearly 7-fold directly below Flaming Gorge dam compared to upstream of the reservoir (Table 3).

Although POC loads were lower directly below both dams compared to above, POC concentrations increased within 


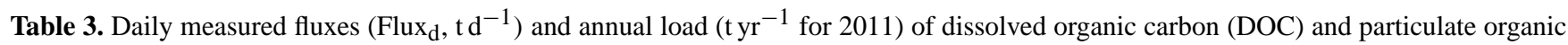
carbon (POC) across sampling sites on the Green and Yampa rivers. Letters A-G preceding the site names correspond to sites A-G in Fig. 1.

\begin{tabular}{|c|c|c|c|c|c|c|c|c|c|c|c|c|c|c|}
\hline \multirow[b]{2}{*}{ Date } & \multicolumn{2}{|c|}{$\begin{array}{l}\text { A: Above } \\
\text { Fontenelle } \\
\text { reservoir }\end{array}$} & \multicolumn{2}{|c|}{$\begin{array}{l}\text { B: Below } \\
\text { Fontenelle } \\
\text { dam }\end{array}$} & \multicolumn{2}{|c|}{$\begin{array}{l}\text { C: Fontenelle } \\
\text { tailwater }\end{array}$} & \multicolumn{2}{|c|}{$\begin{array}{c}\text { D: Above Flaming } \\
\text { Gorge } \\
\text { reservoir }\end{array}$} & \multicolumn{2}{|c|}{$\begin{array}{c}\text { E: Below Flaming } \\
\text { Gorge } \\
\text { dam }\end{array}$} & \multicolumn{2}{|c|}{$\begin{array}{c}\text { F: Flaming Gorge } \\
\text { tailwater }\end{array}$} & \multicolumn{2}{|c|}{$\begin{array}{l}\text { G: Yampa } \\
\text { River }\end{array}$} \\
\hline & DOC & POC & DOC & POC & DOC & POC & DOC & POC & DOC & POC & DOC & POC & DOC & POC \\
\hline 30 Apr 11 & 5.9 & 1.0 & 15.7 & 1.7 & 16.3 & 3.7 & 16.5 & 5.6 & 36.6 & 1.9 & 39.0 & 9.8 & 64.1 & 53.5 \\
\hline 18 May 11 & 26.9 & 23.8 & 24.6 & 5.3 & 24.0 & 10.8 & 17.3 & 15.1 & 36.6 & 2.6 & 41.4 & 8.6 & 161.7 & 231.4 \\
\hline 1 Jun 11 & 28.2 & 11.2 & 33.5 & 5.2 & 34.6 & 8.3 & 34.3 & 22.1 & 39.6 & 2.3 & 43.4 & 9.1 & 174.6 & 282.2 \\
\hline 15 Jun 11 & 84.5 & 49.4 & 65.8 & 9.7 & 67.1 & 18.2 & 54.9 & 23.1 & 74.5 & 2.6 & 74.2 & 16.3 & 163.6 & 140.7 \\
\hline 30 Jun 11 & 125.5 & 14.9 & 101.3 & 8.1 & 103.0 & 38.8 & 97.5 & 33.8 & 83.4 & 3.3 & 81.1 & 12.9 & 111.5 & 86.4 \\
\hline 21 Aug 11 & 5.9 & 0.9 & 12.1 & 0.5 & 12.3 & 1.3 & 11.1 & 2.3 & 23.1 & 0.9 & 22.8 & 2.3 & 8.9 & 1.3 \\
\hline 11 Sep 11 & 3.6 & 0.4 & 7.4 & 0.6 & 7.8 & 1.2 & 8.6 & 1.1 & 23.3 & 1.0 & 23.3 & 1.8 & 5.0 & 0.5 \\
\hline 16 Oct 11 & 3.1 & 0.2 & 7.7 & 0.4 & 8.0 & 0.7 & 7.8 & 0.8 & 19.0 & 0.3 & 18.7 & 0.7 & 4.0 & 0.2 \\
\hline Annual load* & 7604 & 2092 & 7641 & 715 & 7850 & 2106 & 8049 & 2341 & $9430^{* *}$ & 350 & $9674^{* *}$ & 1316 & 13717 & 13189 \\
\hline $2.5 \% \mathrm{CI}$ & 4888 & 663 & 6890 & 315 & 6943 & 1041 & 7278 & 1356 & 8489 & 236 & 9050 & 1023 & 11603 & 7351 \\
\hline $97.5 \% \mathrm{CI}$ & 11868 & 6885 & 8475 & 1668 & 8880 & 4338 & 8904 & 4209 & 10081 & 520 & 10044 & 1694 & 16235 & 23835 \\
\hline
\end{tabular}

* A regression model to estimate daily organic carbon concentrations $[\mathrm{OC}]$ from mean discharge $(Q), \ln ([Q])=\beta_{0}+\beta_{1} \ln ([Q])+\beta_{2} \ln ([Q])^{2}$, was fit for each sampling site in order to estimate annual $[\mathrm{OC}]$ loads. ${ }^{* *}$ No significant relationship between $[\mathrm{OC}]$ and $Q$; therefore annual loads were calculated by using the mean measured $[\mathrm{OC}]$ to estimate daily fluxes.

their tailwaters (Fig. 2). POC concentrations rebounded 2fold at the Fontenelle tailwater site relative to directly below the dam (paired $t$ test, $p<0.0001$ ) and averaged $0.9 \mathrm{mg} \mathrm{L}^{-1}$. Higher POC concentrations resulted in an annual POC load that was nearly 3-fold greater at the Fontenelle tailwater site compared to directly below the dam, although the annual load estimates were highly variable (Table 3 ). POC concentrations averaged $0.6 \mathrm{mg} \mathrm{L}^{-1}$ at the Flaming Gorge tailwater site, which equated to a 3-fold increase in concentration (paired $t$ tests, $p<0.0001$ ) and an annual POC load for 2011 nearly 4-fold greater relative to directly below the dam (Table 3$)$.

Variation in DOC concentrations and the annual load of DOC along the Green River was less pronounced than that for POC. Mean DOC concentrations did not vary above and below either reservoir during 2011 (paired $t$ test, $p>0.1$ for both reservoirs). However, snowmelt DOC concentrations above both reservoirs were greater than DOC concentrations directly below their respective dams, and vice versa during base flow conditions. Similar to the Yampa River, DOC concentrations peaked prior to peak discharge above Fontenelle reservoir, but peaked with discharge below the reservoir (Fig. 2). Although mean DOC concentrations did not differ, higher discharge below Flaming Gorge dam compared to upstream of the reservoir equated to potentially a $1400 \mathrm{t} \mathrm{yr}^{-1}$ increase in DOC annual load below the dam compared to above the reservoir (Table 3).

Mean DOC concentrations increased from directly below both dams through their tailwater reaches, resulting in approximately $200-244 \mathrm{tyr}^{-1}$ of DOC. The DOC concentration directly below Fontenelle dam averaged $3.4 \mathrm{mg} \mathrm{L}^{-1}$ compared to the tailwater sampling site, which averaged $3.5 \mathrm{mg} \mathrm{L}^{-1}$ (paired $t$ test, $p=0.018$ ). The error associated with the annual load estimates was high, but this concentration increase in DOC equated to potentially a $200 \mathrm{t}$ in- crease in the annual DOC load within the $39.6 \mathrm{~km}$ reach (Table 3). DOC concentration averaged $3.7 \mathrm{mg} \mathrm{L}^{-1}$ at the Flaming Gorge tailwater sampling site compared to $3.6 \mathrm{mg} \mathrm{L}^{-1} \mathrm{di}$ rectly below Flaming Gorge dam (paired $t$ test; $p<0.0001$ ). Similar to the Fontenelle tailwater, although the annual load estimates were highly variable, the increase in DOC concentration between the two sampling sites equated to an annual load of $244 \mathrm{t}$ of DOC within the $25.7 \mathrm{~km}$ Flaming Gorge tailwater reach (Table 3 ).

\subsection{DOC bioavailability and composition}

DOC bioavailability, as measured by the decay rate $k\left(\mathrm{~d}^{-1}\right)$ of DOC, was lower directly downstream of both reservoirs than the bioavailability of the DOC upstream (Fig. 3, Table B1). Mean bioavailability above Fontenelle reservoir was $0.0036 \mathrm{~d}^{-1}$, compared to $0.0024 \mathrm{~d}^{-1}$ directly below the dam (paired $t$ test, $p=0.0005)$. Average DOC bioavailability was 2-fold greater above $\left(0.0030 \mathrm{~d}^{-1}\right)$ Flaming Gorge reservoir compared to directly below the dam $\left(0.0014 \mathrm{~d}^{-1}\right.$, paired $t$ test, $p=0.0002)$. Some seasonal variation in bioavailability was measured where $k\left(\mathrm{~d}^{-1}\right)$ was higher during onset of snowmelt but decreased and remained relatively constant through the remaining snowmelt and base flow conditions (Table B1).

Bioavailability was greater at the tailwater sites relative to sampling sites directly below their respective dams (Fig. 3, Table B1). Bioavailability of DOC significantly increased from directly below Fontenelle dam to the tailwater site downstream $\left(0.0024\right.$ to $0.0030 \mathrm{~d}^{-1}$; paired $t$ test, $\left.p=0.04\right)$. Although $k\left(\mathrm{~d}^{-1}\right)$ increased from directly below Flaming Gorge reservoir to the tailwater site downstream, this difference was not statistically significant $\left(0.0014\right.$ to $0.0018 \mathrm{~d}^{-1}$; paired $t$ test, $p=0.09$ ) 


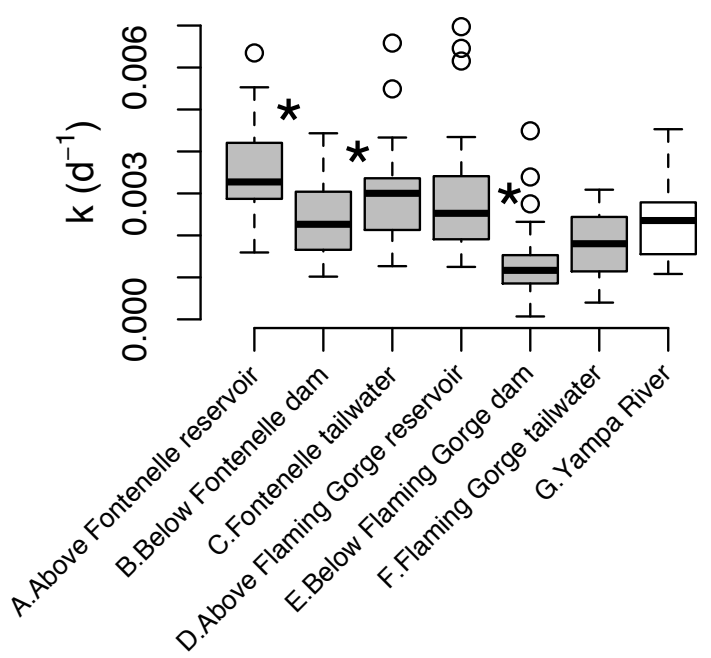

Figure 3. Dissolved organic carbon (DOC) bioavailability across all sampling sites as measured by the DOC decay rate per day $\left(k, \mathrm{~d}^{-1}\right)$. The black line represents the median value of $k\left(\mathrm{~d}^{-1}\right)$, the boxes are the upper and lower 25 th and 75 th percentile, the tails represent the smallest or largest values within 1.5 times the size of the box, and the open circles are considered outliers as they exceed 1.5 times from the 25 th or 75 th percentile. The asterisk $\left(^{*}\right)$ indicates significant differences (paired $t$ test, $p<0.05$ ) in bioavailability between sites. Letters A-G preceding the site names correspond to sites A-G in Fig. 1.

The most pronounced changes in DOC composition, as measured by $S_{\mathrm{R}}$ and $\mathrm{SUVA}_{254}$, were between the sampling sites upstream of Flaming Gorge reservoir and directly downstream of the dam. $S_{\mathrm{R}}$ increased, and $\mathrm{SUVA}_{254}$ decreased from above Flaming Gorge reservoir to directly below its dam (Fig. 4). DOC composition directly below Flaming Gorge dam reflected less aromatic and lower-molecularweight DOC compared to more aromatic and highermolecular-weight DOC above the reservoir ( $t$ test, $\mathrm{SUVA}_{254}$ : $\left.p<0.0001, S_{\mathrm{R}}: p<0.0001\right)$. In comparison, $\mathrm{SUVA}_{254}$ and $S_{\mathrm{R}}$ remained relatively unchanged above and below Fontenelle reservoir, although composition shifted at each site during the transition from snowmelt to base flow (Fig. 4).

DOC composition, based on $\mathrm{SUVA}_{254}$ and $S_{\mathrm{R}}$, varied little through the tailwater reaches. SUVA 254 decreased from directly below Fontenelle reservoir to the Fontenelle tailwater site, indicating less aromatic DOC (mean difference $=0.04 \mathrm{~L} \mathrm{mg} \mathrm{C}^{-1} \mathrm{~m}^{-1}$, paired $t$ test, $p<0.0001$ ), but there was no statistically significant difference in $S_{\mathrm{R}}$ between these sites (paired $t$ tests, $p=0.1$ ). Flaming Gorge tailwater reach had no effect on $\mathrm{SUVA}_{254}$ or $S_{\mathrm{R}}$ (SUVA 254 : paired $t$ test, $p=0.27, S_{\mathrm{R}}$ : paired $t$ tests, $p=0.08$ ).
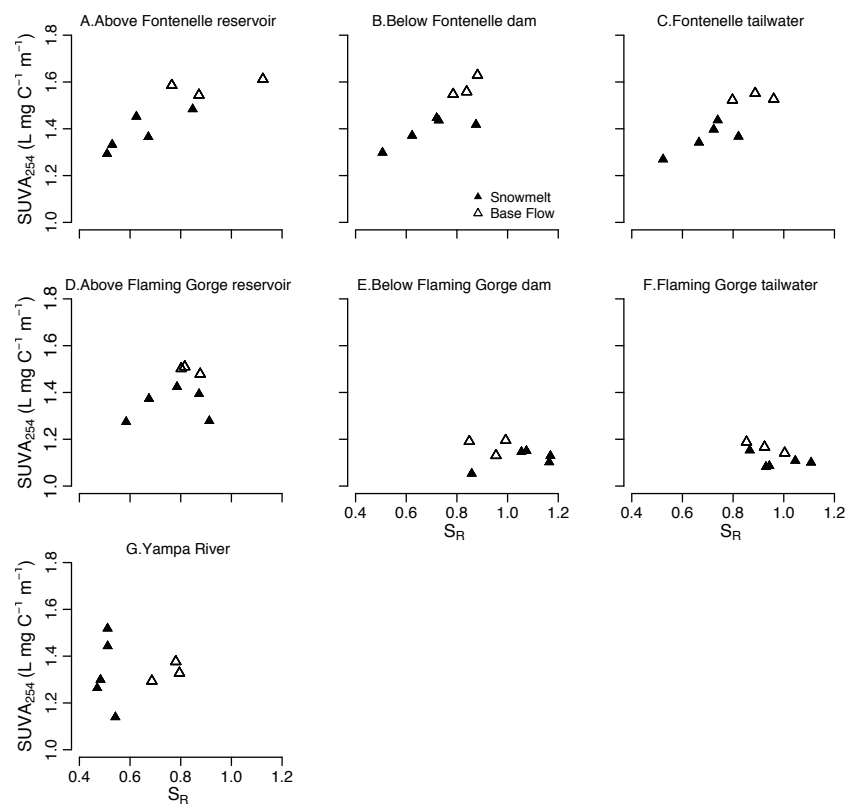

Figure 4. Mean specific ultraviolet absorbance at $254 \mathrm{~nm}$ $\left(\mathrm{SUVA}_{254}, \mathrm{~L} \mathrm{mg} \mathrm{C}^{-1} \mathrm{~m}^{-1}\right.$ ) plotted by the mean slope ratio $\left(S_{\mathrm{R}}\right)$ across sampling dates for each site during snowmelt and base flow conditions. Higher $\mathrm{SUVA}_{254}$ and lower $S_{\mathrm{R}}$ indicate greater aromaticity and higher-molecular-weight DOC compared to lower SUVA $_{254}$ and higher $S_{\mathrm{R}}$, which indicate lower aromaticity and lower molecular weight of DOC. Letters A-G preceding the site names correspond to sites A-G in Fig. 1.

\section{Discussion}

Impoundments on rivers may disrupt longitudinal OC transport (Ward and Stanford, 1983; Miller, 2012; Stackpoole et al., 2014); however, the combination of reservoir-tailwater ecosystems on OC dynamics is less understood than the impact of reservoirs alone. By measuring OC concentrations and DOC composition and bioavailability, we found that longitudinal OC dynamics fluctuated in the presence of reservoir-tailwater ecosystems. POC concentrations and DOC bioavailability were reduced below both reservoirs compared to upstream reaches and OC was produced within the tailwaters. We will discuss how these combined effects of reservoirs and corresponding tailwater river reaches likely increased the impact on OC cycling compared to the presence of impoundments alone by magnifying the transformation of both POC and DOC.

\subsection{Temporal OC dynamics}

Hydrological seasonality drove variation in POC and DOC concentrations in the upper Green and Yampa rivers (Fig. 2). The hydrological flushing hypothesis posits that terrestrial carbon within the watershed accrues during low flows and is flushed into streams and rivers during the initial infiltration of meltwater during the onset of snowmelt (Hornberger et al., 
1994; Boyer et al., 1997). Therefore, our findings of peak OC concentrations preceding peak discharge were not surprising above Fontenelle reservoir and at the Yampa River sampling site. This pattern indicates the terrestrial supply of DOC is exhausted, resulting in hysteresis between DOC concentration and stream discharge (Hornberger et al., 1994; Finlay et al., 2006; Ågren et al., 2008). In comparison, peak concentrations of OC coincided with peak discharge below Fontenelle reservoir, which was likely driven by a combination of factors including dam operations and longer residence time of water in the reservoir relative to the river. For instance, a similar finding of peak OC concentration with peak discharge was found below natural alpine lakes in Idaho, USA, which was attributed to residence time of the lake (Goodman et al., 2011).

Riverine DOC sources, and therefore bioavailability and composition, can be seasonally dependent. The initial flushing of terrestrial $\mathrm{OC}$ from a watershed during early snowmelt can be more bioavailable than base flow DOC because shallow subsurface runoff from the catchment can export stored terrestrial OC into aquatic ecosystems (Michaelson et al., 1998; Pacific et al., 2010; Pellerin et al., 2011). In contrast, DOC composition in semi-arid and arid rivers reflected autochthonous DOC during base flow conditions as opposed to high flows, due to the contribution of algal and microbial exudates from increased primary production (Westerhoff and Anning, 2000). High-sustained flows during spring and summer 2011 in the Yampa and Green rivers (Fig. 2) likely decreased the onset and magnitude of primary production (Uehlinger, 2000), which could account for our findings of stable, as opposed to increasing, DOC bioavailability after peak snowmelt. Furthermore, increased $\mathrm{SUVA}_{254}$ and $S_{\mathrm{R}}$ indicated that base flow DOC likely comprised more aromatic but lower-molecular-weight carbon molecules than snowmelt DOC, likely due to microbial or photo-transformation of DOC (Helms et al., 2008; Kraus et al., 2011; Miller, 2012) as opposed to production of labile DOC (Weishaar et al., 2003; Goodman et al., 2011). Transformation of DOC, rather than production of labile DOC from algal exudation, supports our DOC bioavailability findings.

\subsection{Longitudinal OC dynamics}

Not only total water storage but also reservoir size may alter DOC dynamics and longitudinal transport. The annual DOC loads $\left(\mathrm{tyr}^{-1}\right)$ above Fontenelle reservoir and directly below the dam were similar (Table 3 ). In comparison, there was greater difference in DOC annual load from upstream to downstream of Flaming Gorge reservoir, where the DOC annual load increased downstream of the reservoir in comparison to upstream of the reservoir. These annual DOC loads for the Green River were similar to the upper Colorado River with comparable drainage areas (Fig. 5, Miller, 2012; Stackpoole et al., 2014), yet the increase in DOC annual load with drainage area was greater

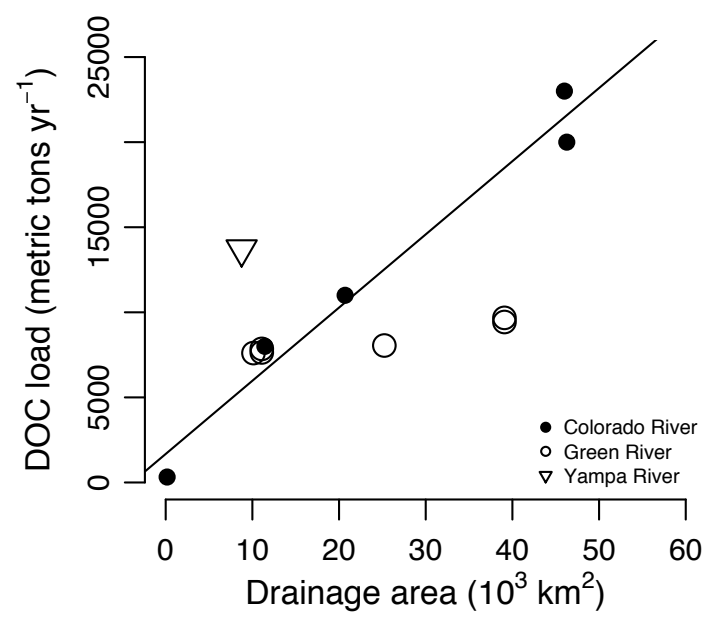

Figure 5. Annual DOC load $\left(\mathrm{t} \mathrm{yr}^{-1}\right)$ plotted against drainage area $\left(\mathrm{km}^{2}\right)$ from the Green, Yampa, and upper reaches of the Colorado River $\left(<50 \times 10^{3} \mathrm{~km}^{2}\right.$; data from Stackpoole et al., 2014, Miller, 2012). Linear regression line was fitted through data from the upper Colorado River where DOC load $\left(\mathrm{t} \mathrm{yr}^{-1}\right)=1675.7+430.1 \times \mathrm{km}^{2}$, $\left.P=0.0001, r^{2}=0.98\right)$.

in the upper Colorado River (drainage area $<50000 \mathrm{~km}^{2}$ ) compared to the Green River (Fig. 5). The upper Colorado River had approximately $4.6 \mathrm{~km}^{3}$ of reservoir storage dispersed among 464 dams within the upper reaches (drainage area $<46300 \mathrm{~km}^{2}$ ) (Miller, 2012). Similarly, the Green River directly downstream of Flaming Gorge dam has a drainage area of $39083 \mathrm{~km}^{2}$, and in 2011 the mean reservoir storage was approximately $4.3 \mathrm{~km}^{3}$ (Table A1), but most of the storage was within Flaming Gorge reservoir. The difference in the relationship of DOC fluxes with watershed area between the upper Colorado River and Green River suggests reservoir scheme (i.e., many small versus a few large reservoirs) may drive a decrease in OC loads in this semi-arid watershed.

Residence time likely drove, at least in part, the longitudinal DOC concentration and flux patterns we observed in relation to the reservoirs, although we do not have the appropriate data to adequately budget $\mathrm{OC}$ for either of the reservoirs. Increased residence time due to impounding a river reduces water velocity, which allows POC to settle and allows more time for the production and transformation of DOC (Mash et al., 2004; Kraus et al., 2011; Knoll et al., 2013). Residence time explained a similar shift in DOC concentration and timing of peak discharge above and below natural alpine lakes in snowmelt-dominated catchments in Idaho, USA (Goodman et al. 2011). The timing of reservoir filling and dam operations resulted in an arid reservoir in Arizona, USA (Westerhoff and Anning, 2000), and two temperate reservoirs located in Ohio, USA (Knoll et al., 2013), fluctuating between net source and net sink of DOC to downstream reaches. Also, seasonal shifts in reservoir primary production drove a reservoir in California, USA, to shift between a DOC source and sink (Kraus et al., 2011). A combination of residence time 
and autochthonous production within reservoirs may lead to production (Parks and Baker, 1997; Kraus et al., 2011) or loss of DOC (Kraus et al., 2011; Miller et al., 2012; Knoll et al., 2013) to downstream ecosystems, likely driven by magnitude of hydrological variation such as high- versus low-flow years (Knoll et al., 2013).

DOC composition differed from upstream to downstream of both Fontenelle and Flaming Gorge reservoirs. All SUVA $_{254}$ values were $<3 \mathrm{~L} \mathrm{mg} \mathrm{C}^{-1} \mathrm{~m}^{-1}$, which indicates that DOC across our sampling sites was of low aromatic content (Weishaar et al., 2003), similar to values found in the Colorado River (Miller, 2012). Despite this low range of values, DOC composition below Flaming Gorge dam was less aromatic (as indicated by $\mathrm{SUVA}_{254}$ ) and reflected lower-molecular-weight OC (as indicated by $S_{\mathrm{R}}$ ) compared to DOC composition upstream (Fig. 3). These small, but statistically significant, changes could be due to photodegradation (Brooks et al., 2007; Kraus et al., 2011; Cory et al., 2014) coupled with autochthonous production of DOC (Chin et al., 1994; Nguyen et al., 2002). A similar decreasing SUVA 254 pattern from upstream to downstream of reservoirs was reported below Lake Powell and Lake Mead in the lower Colorado River basin (Miller, 2012). In addition, DOC bioavailability was reduced below Flaming Gorge dam compared to upstream of the reservoir (Fig. 3). This pattern along with our absorbance data indicates that DOC exported from Flaming Gorge reservoir was likely a combination of transformed and microbially produced DOC. In comparison, DOC composition did not vary above and below Fontenelle reservoir based on $\mathrm{SUVA}_{254}$ and $S_{\mathrm{R}}$ metrics. But, similar to Flaming Gorge reservoir, bioavailability of DOC was significantly lower below Fontenelle dam compared to above the reservoir (Fig. 3). Reduced bioavailability below the dam indicates that, even with no observed spectral changes (i.e., SUVA $_{254}$ and $S_{R}$ ) above and below Fontenelle reservoir, DOC processing or transformation occurred within this reservoir ecosystem, but to a lesser extent than the larger Flaming Gorge reservoir.

POC concentrations were 10-fold lower downstream of Fontenelle and Flaming Gorge dams when compared to upstream of both reservoirs (Fig. 2), and subsequently resulted in a reduced POC flux and annual load for Flaming Gorge reservoir and a marginal reduction for Fontenelle reservoir (Table 3). This pattern is well established for large impoundments on rivers; impoundments allow for the settling of POC (Friedl and Wüest, 2002; Downing et al., 2008; Tranvik et al., 2009). We did not measure within reservoir OC fate, but the fate of buried POC in reservoirs was likely a combination of preservation (Downing et al., 2008), mineralization to $\mathrm{CO}_{2}$ (St. Louis et al., 2000; Knoll et al., 2013), and transformation to DOC (Meyer et al., 1998).

\subsection{Tailwater organic carbon transport}

Despite the low POC concentration emanating from Fontenelle and Flaming Gorge dams, POC concentrations increased to $40-74 \%$ of concentrations measured upstream of the reservoirs within the short tailwater reaches. There were no perennial tributaries in either tailwater; therefore the POC fluxes from the tailwater reaches were likely of autochthonous origin. Primary production likely drove this flux of POC from both tailwater reaches (Table 3). Tailwaters have high primary production (Webster et al., 1979; Davis et al., 2011) where algae and particulates are sloughed during discharge releases from the dam (Perry and Perry, 1991). The annual POC load from Fontenelle reservoir tailwater was similar to the annual POC load into the reservoir, indicating that an equivalent amount of the POC load reduced from above to below the reservoir was generated within the $39.6 \mathrm{~km}$ tailwater. Similarly, the Flaming Gorge tailwater generated about half the amount of POC that entered the reservoir (Table 3 ). Recognizing the high variability in our annual load estimates, we compared the potential POC load to potential primary production within the reach. We estimated POC area-specific fluxes from the tailwaters by dividing the difference in POC annual load $\left(\mathrm{g} \mathrm{yr}^{-1}\right)$ by reach area $\left(\mathrm{m}^{2}\right)$ and $365\left(\mathrm{~d}^{-1}\right)$. The POC daily flux from Fontenelle tailwater was potentially $1.9 \mathrm{~g} \mathrm{C} \mathrm{m}^{-2} \mathrm{~d}^{-1}$ and from Flaming Gorge tailwater $1.3 \mathrm{~g} \mathrm{C} \mathrm{m}^{-2} \mathrm{~d}^{-1}$. Although we did not measure primary production in Flaming Gorge tailwater, primary production in Fontenelle tailwater can be has high as $8.1 \mathrm{~g} \mathrm{C} \mathrm{m}^{-2} \mathrm{~d}^{-1}$ (Hall et al., 2015). Also, these POC areaspecific flux estimates were within the upper 50th percentile of gross primary production measurements from 72 streams, showing that primary production can support this high OC flux (Bernot et al., 2010). The POC flux likely consisted of current primary production and organic matter from primary production accrued throughout the year. Low discharge releases from Fontenelle and Flaming Gorge dams during the winter months combined, with the increased flows released from the dam during the onset of our sampling (Fig. 2), likely flushed the organic matter that had accrued within the tailwaters throughout the year (Parks and Baker, 1997; Brooks et al., 2007).

Fontenelle and Flaming Gorge tailwaters were likely a source of autochthonously produced DOC. Similar to POC annual loads, we recognized the high variability in the DOC annual loads, but we also compared the potential daily flux of DOC to plausible primary production fluxes. The daily estimated flux of DOC from the tailwaters were 4- to 6-fold lower than POC fluxes, $0.3 \mathrm{~g} \mathrm{C} \mathrm{m}^{-2} \mathrm{~d}^{-1}$ for both Fontenelle and Flaming Gorge tailwaters. Autochthonous DOC fluxes were similar from the tailwater segment directly below Lake Powell on the Colorado River $\left(0.3-2.1 \mathrm{~g} \mathrm{C} \mathrm{m}^{-2} \mathrm{~d}^{-1}\right)$, and these fluxes were positively correlated with gross primary production (Ulseth, 2012). In addition, autochthonous DOC fluxes in the Grand Canyon reach of the Colorado River ranged from 0.09 to $0.39 \mathrm{~g} \mathrm{C} \mathrm{m}^{-2} \mathrm{~d}^{-1}$ (Ulseth, 2012). Although estimated DOC fluxes were lower than POC fluxes, they were within the lower 50th percentile of primary production rates across 72 streams in North America (Bernot 
et al., 2010), indicating that autochthonously derived DOC flux, similar to POC flux, was potentially a substantial proportion of primary production (Hotchkiss and Hall, 2014) from these tailwater ecosystems. The DOC flux from tailwater algae had a minimal effect on total DOC composition, given our absorbance data. However, bioavailability was higher at the Fontenelle tailwater compared to directly below the dam, suggesting freshly produced, labile DOC. Increased total DOC bioavailability from the tailwater likely produced an export of labile DOC, potentially subsidizing the microbial food web in the downstream reaches.

The net effect of dams on the reduction of OC (POC + DOC) transport was essentially low ( 6-14\%, (an${\left.\text { nual } \text { load }_{\text {in }}-\text { annual load }_{\text {out }}\right) / \text { annual load }}_{\text {in }} \times 100$, Table 3 ) given the high error associated with our flux estimates and in comparison to the changes in POC annual load alone (66-85\%) and likely POC and DOC composition. This finding affects how impoundments are viewed from an OC cycling perspective. We potentially underestimated the effect of impounding rivers on $\mathrm{OC}$ fluxes in the upper basin of the Colorado River because total concentration based fluxes do not represent transformation processes in river-reservoirtailwater ecosystems.
The Fontenelle and Flaming Gorge tailwater ecosystems contributed to the effect of reservoirs on OC transport in the Green River by increasing the export of likely autochthonous OC downriver. Therefore, the reservoirs regulated OC transport by reducing POC and altering the composition and bioavailability of DOC. We suggest that the effect of impounding rivers on $\mathrm{C}$ cycling is larger than the reservoirs alone because of the additive impacts of tailwater reaches, which produce and then export a comparable amount of autochthonous OC to what is likely stored behind dams. However, accurately quantifying annual fluxes of OC can be difficult, as illustrated by the potential variability in our annual load estimates (Table 3). To assess the effects in terms of regional carbon budgets, we need to consider not only reservoirs in regards to their capacity to transform terrestrial OC (Knoll et al., 2013) but also the additive effects of their tailwater ecosystems. 


\section{Appendix A}

Table A1. Fontenelle and Flaming Gorge reservoir volumes and residence time $\left(R_{\mathrm{t}}\right)$ for 2011. $R_{\mathrm{t}}$ was calculated by dividing reservoir volume (volume, $\mathrm{m}^{3}$ ) by yearly outflow $\left(Q_{\text {out }}, \mathrm{m}^{3} \mathrm{yr}^{-1}\right)$. Mean residence time was based on mean $Q_{\text {out }}$ for 2011 , including both base flow and snowmelt. Minimum residence time was based on $Q_{\text {out }}$ during snowmelt period of discharge. Maximum residence time was based on base flow $Q_{\text {out }}$ only.

\begin{tabular}{lrr}
\hline Reservoir & Mean volume* $(\min , \max ) \mathrm{km}^{3}$ & Mean $R_{\mathrm{t}}(\min , \max ) \mathrm{yr}^{-1}$ \\
\hline Fontenelle & $0.26(0.12,0.40)$ & $0.13(0.06,0.30)$ \\
Flaming Gorge & $4.08(3.79,4.43)$ & $1.61(0.86,2.81)$ \\
\hline
\end{tabular}

* Volume data and $Q_{\text {out }}$ for Fontenelle and Flaming Gorge reservoirs for 2011 were accessed from the Bureau of Reclamation Upper Colorado River Region Water Operations (www.usbr.gov/uc/). 


\section{Appendix B}

Table B1. Mean decay rates $\left(k, \mathrm{~d}^{-1}\right)$ and mean percentage $(\%)$ loss of DOC over 28-day bioassay experiment. Mean percentage loss was calculated by dividing the difference in DOC concentration $\left(\mathrm{mg} \mathrm{L}^{-1}\right)$ from day 0 to day 28 by the initial DOC concentration at day 0 and then multiplying by 100 . The $95 \%$ confidence intervals were calculated for $k \mathrm{~d}^{-1}$ and \% loss of DOC from three replicate bioassay experiments for each site and each date. Letters A-G preceding the site names correspond to sites A-G in Fig. 1.

\begin{tabular}{|c|c|c|c|}
\hline Site & Date & Mean $k\left(\mathrm{~d}^{-1}\right)(95 \% \mathrm{CI})$ & Mean $\%$ loss DOC $\left(28 \mathrm{~d}^{-1}\right)(95 \% \mathrm{CI})$ \\
\hline A: Above Fontenelle reservoir & 30 Apr 11 & $0.0056(0.0051,0.0063)$ & $14.4(12.7,15.4)$ \\
\hline A: Above Fontenelle reservoir & 18 May 11 & $0.0024(0.0017,0.0029)$ & $7.3(4.5,9.6)$ \\
\hline A: Above Fontenelle reservoir & 1 Jun 11 & $0.0029(0.0023,0.0037)$ & $8.5(6.8,11.0)$ \\
\hline A: Above Fontenelle reservoir & 15 Jun 11 & $0.0036(0.0031,0.0042)$ & $10.4(7.8,13.3)$ \\
\hline A: Above Fontenelle reservoir & 30 Jun 11 & $0.0031(0.0029,0.0032)$ & $7.7(7.2,8.0)$ \\
\hline A: Above Fontenelle reservoir & 21 Aug 11 & $0.0044(0.0040,0.0050)$ & $10.9(10.4,11.4)$ \\
\hline A: Above Fontenelle reservoir & 11 Sep 11 & $0.0025(0.0020,0.0029)$ & $7.5(5.8,9.0)$ \\
\hline A: Above Fontenelle reservoir & 16 Oct 11 & $0.0043(0.0037,0.0050)$ & $11.4(9.3,14.6)$ \\
\hline B: Below Fontenelle dam & 30 Apr 11 & $0.0036(0.0032,0.0040)$ & $10.7(9.7,11.6)$ \\
\hline B: Below Fontenelle dam & 18 May 11 & $0.0038(0.0034,0.0043)$ & $7.4(7.3,7.7)$ \\
\hline B: Below Fontenelle dam & 1 Jun 11 & $0.0021(0.0016,0.0027)$ & $5.5(3.8,7.2)$ \\
\hline B: Below Fontenelle dam & 15 Jun 11 & $0.0020(0.0014,0.0024)$ & $5.6(4.1,6.5)$ \\
\hline B: Below Fontenelle dam & 30 Jun 11 & $0.0020(0.0017,0.0023)$ & $5.4(4.4,6.1)$ \\
\hline B: Below Fontenelle dam & 21 Aug 11 & $0.0019(0.0014,0.0023)$ & $5.0(4.7,5.4)$ \\
\hline B: Below Fontenelle dam & 11 Sep 11 & $0.0020(0.0013,0.0028)$ & $5.6(3.27 .9)$ \\
\hline B: Below Fontenelle dam & 16 Oct 11 & $0.0016(0.0011,0.0021)$ & $4.8(2.3,6.9)$ \\
\hline C: Fontenelle tailwater & 30 Apr 11 & $0.0055(0.0044,0.0065)$ & $16.6(13.4,19.5)$ \\
\hline C: Fontenelle tailwater & 18 May 11 & $0.0024(0.0017,0.0032)$ & $5.6(4.6,7.0)$ \\
\hline C: Fontenelle tailwater & 1 Jun 11 & $0.0030(0.0026,0.0034)$ & $9.0(7.8,11.0)$ \\
\hline C: Fontenelle tailwater & 15 Jun 11 & $0.0032(0.0030,0.0034)$ & $9.2(8.5,9.6)$ \\
\hline C: Fontenelle tailwater & 30 Jun 11 & $0.0025(0.0016,0.0031)$ & $6.4(3.5,8.2)$ \\
\hline C: Fontenelle tailwater & 21 Aug 11 & $0.0025(0.0023,0.0026)$ & $4.4(3.7,5.1)$ \\
\hline C: Fontenelle tailwater & 11 Sep 11 & $0.0022(0.0013,0.0035)$ & $6.2(2.4,10.6)$ \\
\hline C: Fontenelle tailwater & 16 Oct 11 & $0.0023(0.0018,0.0032)$ & $6.1(3.1,9.1)$ \\
\hline D: Above Flaming Gorge reservoir & 30 Apr 11 & $0.0065(0.0062,0.0069)$ & $17.4(15.9,18.9)$ \\
\hline D: Above Flaming Gorge reservoir & 18 May 11 & $0.0038(0.0035,0.0043)$ & $10.9(9.9,11.7)$ \\
\hline D: Above Flaming Gorge reservoir & 1 Jun 11 & $0.0021(0.0018,0.0024)$ & $5.0(4.0,5.7)$ \\
\hline D: Above Flaming Gorge reservoir & 15 Jun 11 & $0.0022(0.0019,0.0026)$ & $5.2(4.4,5.8)$ \\
\hline D: Above Flaming Gorge reservoir & 30 Jun 11 & $0.0025(0.0021,0.0029)$ & $7.9(6.3,8.8)$ \\
\hline D: Above Flaming Gorge reservoir & 21 Aug 11 & $0.0014(0.0013,0.0016)$ & $2.7(1.4,3.7)$ \\
\hline D: Above Flaming Gorge reservoir & 11 Sep 11 & $0.0021(0.0016,0.0024)$ & $4.8(1.8,7.2)$ \\
\hline D: Above Flaming Gorge reservoir & 16 Oct 11 & $0.0032(0.0031,0.0033)$ & $7.9(6.4,8.9)$ \\
\hline E: Below Flaming Gorge dam & 30 Apr 11 & $0.0010(0.0002,0.0015)$ & $4.8(1.8,6.7)$ \\
\hline E: Below Flaming Gorge dam & 18 May 11 & $0.0009(0.0007,0.0011)$ & $3.3(2.8,4.0)$ \\
\hline E: Below Flaming Gorge dam & 1 Jun 11 & $0.0011(0.0008,0.0014)$ & $4.2(2.5,5.6)$ \\
\hline E: Below Flaming Gorge dam & 15 Jun 11 & $0.0008(0.0005,0.0010)$ & $2.8(1.4,4.4)$ \\
\hline E: Below Flaming Gorge dam & 30 Jun 11 & $0.0028(0.0014,0.0043)$ & $10.3(5.2,14.6)$ \\
\hline E: Below Flaming Gorge dam & 21 Aug 11 & $0.0026(0.0021,0.0033)$ & $8.6(7.9,9.0)$ \\
\hline E: Below Flaming Gorge dam & 11 Sep 11 & $0.0011(0.0009,0.0014)$ & $4.3(3.0,5.6)$ \\
\hline E: Below Flaming Gorge dam & 16 Oct 11 & $0.0011(0.0009,0.0013)$ & $2.1(1.2,2.9)$ \\
\hline F: Flaming Gorge tailwater & 30 Apr 11 & $0.0019(0.0012,0.0029)$ & $8.4(6.5,11.4)$ \\
\hline F: Flaming Gorge tailwater & 18 May 11 & $0.0025(0.0020,0.0030)$ & $8.3(7.2,9.9)$ \\
\hline F: Flaming Gorge tailwater & 1 Jun 11 & $0.0021(0.0017,0.0023)$ & $8.2(6.6,9.1)$ \\
\hline F: Flaming Gorge tailwater & 15 Jun 11 & $0.0005(0.0004,0.0006)$ & $2.1(1.6,2.6)$ \\
\hline F: Flaming Gorge tailwater & 30 Jun 11 & $0.0026(0.0023,0.0029)$ & $8.5(7.0,10.2)$ \\
\hline F: Flaming Gorge tailwater & 21 Aug 11 & $0.0019(0.0012,0.0026)$ & $4.5(0.5,8.0)$ \\
\hline F: Flaming Gorge tailwater & 11 Sep 11 & $0.0015(0.0009,0.0023)$ & $2.5(0.3,4.6)$ \\
\hline F: Flaming Gorge tailwater & 16 Oct 11 & $0.0014(0.0012,0.0016)$ & $3.0(2.4,4.0)$ \\
\hline G: Yampa River & 30 Apr 11 & $0.0043(0.0042,0.0045)$ & $11.7(11.5,11.9)$ \\
\hline G: Yampa River & 18 May 11 & $0.0015(0.0012,0.0020)$ & $2.8(2.2,3.5)$ \\
\hline G: Yampa River & 1 Jun 11 & $0.0013(0.001,0.0015)$ & $3.5(2.5,4.6)$ \\
\hline G: Yampa River & 15 Jun 11 & $0.0017(0.0011,0.0023)$ & $4.3(1.9,6.0)$ \\
\hline G: Yampa River & 30 Jun 11 & $0.0022(0.0017,0.0025)$ & $6.2(5.7,6.8)$ \\
\hline G: Yampa River & 21 Aug 11 & $0.0035(0.0021,0.0044)$ & $10.3(6.9,13.7)$ \\
\hline G: Yampa River & 11 Sep 11 & $0.0024(0.0020,0.0029)$ & $7.0(5.0,9.2)$ \\
\hline G: Yampa River & 16 Oct 11 & $0.0025(0.0024,0.0026)$ & $4.9(3.5,6.8)$ \\
\hline
\end{tabular}


Author contributions. A. J. Ulseth and R. O. Hall Jr. designed the sampling plan. A. J. Ulseth carried out all sampling and sample and data analyses. A. J. Ulseth and R. O. Hall Jr. prepared the manuscript.

Acknowledgements. This research was funded in part by the George S. Menkens Memorial Scholarship from the Zoology and Physiology Department at University of Wyoming to A. J. Ulseth and by a cooperative agreement 05WRAG0055 from the US Geological Survey to R. O. Hall, E. J. Rosi-Marshall, and C. Baxter. Thank you to Harold Bergman, Indy Burke, Ted Kennedy, Bryan Shuman, and Jakob Schelker for insightful comments on the manuscript. We thank Eriek Hansen for GIS assistance.

Edited by: T. J. Battin

\section{References}

Ågren, A., Buffam, I., Berggren, M., Bishop, K., Jansson, M., and Laudon, H.: Dissolved organic carbon characteristics in boreal streams in a forest-wetland gradient during the transition between winter and summer, J. Geophys. Res., 113, G03031, doi:10.1029/2007JG000674, 2008.

Aufdenkampe, A. K., Mayorga, E., P. A. Raymond, P. A., Melack, J. M., Doney, A. C., Alin, S. R., Aalto, R. E., and Yoo, K.: Riverine coupling of biogeochemical cycles between land, oceans, and atmosphere, Front. Ecol. Environ., 9, 53-60, 2011.

Baines, S. B. and Pace, M. L.: The production of dissolved organic matter by phytoplankton and its importance to bacteria: Patterns across marine and freshwater systems, Limnol. Oceanogr., 36, 1078-1090, 1991.

Bano, N., Moran, M. A., and Hodson, R. E.: Bacterial utilization of dissolved humic substances from a freshwater swamp, Aquat. Microb. Ecol., 12, 233-238, 1997.

Battin, T. J., Luyssaert, S., Kaplan, L. A., Aufdenkampe, A. K., Richter, A., and Tranvik, L. J.: The boundless carbon cycle, Nat. Geosci., 2, 598-600, 2009.

Benenati, E. P., Shannon, J. P., Hagan, J. S., and Blinn, D. W.: Drifting fine particulate organic matter below Glen Canyon Dam in the Colorado River, Arizona, J. Freshwater Ecol., 16, 235-248, 2001.

Benke, A. C.: A perspective on America's vanishing streams, J. N. Am. Benthol. Soc., 9, 77-88, 1990.

Bernot, M. J., Sobota, D. J., Hall, R. O., Mulholland, P. J., Dodds, W. K., Webster, J. R., Tank, J. L., Ashkenas, L. R., Cooper, L. W., Dahm, C. N., Gregory, S. V., Grimm, N. B., Hamilton, S. K., Johnson, S. L., McDowell, W. H., Meyer, J. L., Peterson, B., Poole, G. C., Valett, H. M., Arango, C., Beaulieu, J. J., Burgin, A. J., Crenshaw, C., Helton, A. M., Johnson, L., Merriam, J., J., Niederlehner, B. R., O’Brien, J. M., Potter, J. D., Sheibley, R. W., Thomas, S. M., and Wilson, K.: Inter-regional comparison of land-use effects on stream metabolism, Freshwater Biol., 55, 1874-1890, 2010.

Bertilsson, S. and Jones Jr., J. B.: Supply of dissolved organic matter to aquatic ecosystems: autochthonous sources, Aquatic ecosystems: Interactivity of dissolved organic matter, edited by: Find- lay, S. E. G. and Sinsabaugh, R. L., Academic Press, San Diego, California, USA, 3-25, 2003.

Boyer, E. W., Hornberger, G. M, Bencala, K. E., and McKnight, D. M.: Response characteristics of DOC flushing in an alpine catchment, Hydrol. Process., 11, 1635-1674, 1997.

Brooks, P. D., Haas, P. A., and Huth, A. K.: Seasonal variability in the concentration and flux of organic matter and inorganic nitrogen in a semiarid catchment, San Pedro River, Arizona, J. Geophys. Res., 112, G03S04, doi:10.1029/2006JG000275, 2007.

Chin, Y., Aiken, G., and O'Loughlin, E.: Molecular weight, polydispersity, and spectroscopic properties of aquatic humic substances, Environ. Sci. Technol., 28, 1853-1858, 1994.

Cole, J. J., Prairie, Y. T., Caraco, N. F., McDowell, W. H., Tranvik, L. J., Striegl, R. G., Duarte, C. M., Kortelainen, P., Downing, J. A., Middelburg, J. J., and Melack, J.: Plumbing the global carbon cycle: Integrating inland waters into the terrestrial carbon budget, Ecosystems, 10, 171-184, 2007.

Cory, R. M., Ward, C. P., Crump, B. C., and Kling, G. W.: Sunlight controls water column processing of carbon in arctic fresh waters, Science, 345, 925-928, 2014.

Dalgaard, P.: Introductory Statistics with R, 2nd Edn., Springer, New York, USA, 2008.

Davis, C. J., Fritsen, C. H., Wirthlin, E. D., and Memmott, J. C.: High rates of primary productivity in a semi-arid tailwater: implications for self-regulated production, River Res. Appl., 10, 1820-1829, 2011.

del Giorgio, P. A. and Davis, J.: Patterns in dissolved organic matter lability and consumption across aquatic ecosystems, Aquatic ecosystems: Interactivity of dissolved organic matter, Findlay, S. E. G. and Sinsabaugh, R. L., Academic Press, San Diego, California, USA, 400-424, 2003.

Downing, J. A., Cole, J. J., Middelburg, J. J., Striegl, R. G., Duarte, C. M., Kortelainen, P., Prairie, Y. T., and Laube, K. A.: Sediment organic carbon burial in agriculturally eutrophic impoundments over the last century, Global Biogeochem. Cy., 22, GB1018, doi:10.1029/2006GB002854, 2008.

Finlay, J., Neff, J., Zimov, S., Davydova, A., and Davydov, S.: Snowmelt dominance of dissolved organic carbon in high-latitude watersheds: Implications for characterization and flux of river DOC, Geophys. Res. Lett., 33, L10401, doi:10.1029/2006GL025754, 2006.

Friedl, G. and Wüest, A.: Disrupting biogeochemical cycles - Consequences of damming, Aquat. Sci., 64, 55-65, 2002.

Goodman, K. J., Baker, M. A., and Wurtsbaugh, W. A.: Lakes as buffers of stream dissolved organic matter (DOM) variability: Temporal patterns of DOM characteristics in mountain stream-lake systems, J. Geophys. Res., 116, G00N02, doi:10.1029/2011JG001709, 2011.

Guillemette, F. and del Giorgio, P. A.: Reconstructing the various facets of dissolved organic carbon bioavailability in freshwater ecosystems, Limnol. Oceanogr., 56, 734-748, 2011.

Hall Jr., R. O., Tank, J. L., Baker, M. A., Rosi-Marshall, E. J., and Hotchkiss, E. R.: Metabolism, gas exchange and carbon spiraling in rivers, Ecosystems, in review, 2015.

Helms, J. R., Stubbins, A., Ritchie, J. D., Minor, E. C., Kieber, D. J., and Mopper, K.: Absorption spectral slopes and slope ratios as indicators of molecular weight, source, and photobleaching of chromophoric dissolved organic matter, Limnol. Oceanogr., 53, 955-969, 2008. 
Hornberger, G. M., Bencala, K. E., and McKnight, D. M.: Hydrological controls on dissolved organic carbon during snowmelt in the Snake River near Montezuma, Colorado, Biogeochemistry, 25, 147-165, 1994.

Hotchkiss, E. R. and Hall, R. O.: Whole-stream ${ }^{13} \mathrm{C}$ tracer addition reveals distinct fates of newly fixed carbon, Ecology, 96, 403416, doi:10.1890/14-0631.1, 2014.

Knoll, L. B., Vanni, M. J., Renwick, W. H., Dittman, E. K., and Gephart, J. A.: Temperate reservoirs are large carbon sinks and small $\mathrm{CO}_{2}$ sources: Results from high resolution carbon budgets, Global Biogeochem. Cy., 27, 52-64, doi:10.1002/gbc.20020, 2013.

Kraus, T. E. C., Bergamaschi, B. A., Hernes, P. J., Doctor, D., Kendall, C., Downing, B. D., and Losee, R. F.: How reservoirs alter drinking water quality: Organic matter sources, sinks, and transformations, Lake Reserv. Manage., 27, 205-219, 2011.

Lieberman, D. M. and Burke, T. A.: Particulate organic matter transport in the lower Colorado River, South-Western USA, Regul. River., 8, 323-334, 1993.

Mash, H., Westerhoff, P. K., Baker, L. A., Nieman, R. A., and Nguyn, M.: Dissolved organic matter in Arizona reservoirs: assessment of carbonaceous sources, Org. Geochem., 35, 831-843, 2004.

Meyer, J. L., Wallace, J. B., and Eggert, S. L.: Leaf litter as a source of dissolved organic carbon in streams, Ecosystems, 1, 240-249, 1998.

Michaelson, G. J., Ping, C. L., Kling, G. W., and Hobbie, J. E.: The character and bioactivity of dissolved organic matter at thaw and in the spring runoff waters in the arctic tundra north slope, Alaska, J. Geophys. Res., 103, 28939-28946, 1998.

Miller, M. P.: The influence of reservoirs, climate, land use and hydrologic conditions on loads and chemical quality of dissolved organic carbon in the Colorado River, Water Resour. Res., 48, W00M02, doi:10.1029/2012WR012312, 2012.

Nadon, M. J., Metcalfe, R. A., Williams, C. J., Somers, K. M., and Xenopoulos, M. A.: Assessing the effects of dams and waterpower facilities on riverine dissolved organic matter composition, Hydrobiologia, 744, 145-164, doi:10.1007/s10750-0142069-0, 2014.

Nguyen, M. L., Baker, L. A., and Westerhoff, P.: DOC and DBP precursors in western US watersheds and reservoirs, J. Am. Water Works Ass., 94, 98-112, 2002.

Nilsson, C., Reidy, C. A., Dynesius, M., and Revenga, C.: Fragmentation and flow regulation of the world's large river systems, Science, 308, 405-408, 2005.

Pacific, V. J., Jensco, K. G., and McGlynn, B. L.: Variable flushing mechanisms and landscape structure control stream DOC export during snowmelt in a set of nested catchments, Biogeochemistry, 99, 193-211, doi:10.1007/s10533-009-9401-1, 2010.

Parks, S. J. and Baker, L. A.: Sources and transport of organic carbon in an Arizona River-Reservoir system, Water Res., 31, 17511759, 1997.

Pellerin, B. A., Saraceno, J. F., Shanley, J. B., Sebestyen, S. D., Aiken, G. R., Wollheim, W. M., and Bergamaschi, B. A.: Taking the pulse of snowmelt: in situ sensors reveal seasonal, event and diurnal patterns of nitrate and dissolved organic matter variability in an upland forest stream, Biogeochemistry, 108, 183-198, doi:10.1007/s10533-011-9589-8, 2011.
Perry, S. A. and Perry, W. B.: Organic carbon dynamics in two regulated rivers in northwestern Montana, USA, Hydrobiologia, 218, 193-203, 1991.

R Development Core Team: R: A language and environment for statistical computing, R Foundation for Statistical Computing, Vienna, Austria, http://www.R-project.org/, last access: 9 March 2015.

Sabo, J. L., Sinha, T., Bowling, L. C., Schoups, G. H. W., Wallender, W. W., Campana, M. E., Cherkauer, K. A., Fuller, P. L., Graf, W. L., Hopmans, J. W., Kominoski, J. S., Taylor, C., Trimble, S. W., Webb, R. H., and Wohl, E. E.: Reclaming freshwater sustainability in the Cadillac Desert, P. Natl. Acad. Sci. USA, 107, 21263-21269, 2010.

Schmidt, J. C. and Wilcock, P. R.: Metrics for assessing the downstream effects of dams, Water Resour. Res., 44, W04404, doi:10.1029/2006WR005092, 2008.

Stackpoole, S. M., Stets, E. G., and Striegl, R. G.: The impact of climate and reservoirs on longitudinal riverine carbon fluxes from two major watersheds in the Central and Intermontane West, J. Geophys. Res., 119, 848-863, doi:10.1002/2013JG002496, 2014.

St. Louis, V. L., Kelly, C. A., Duchemin, E., Rudd, J. W. M., and Rosenberg, D. M.: Reservoir surfaces as sources of greenhouse gasses to the atmosphere: A global estimate, BioScience, 50, 766-775, 2000.

Tranvik, L. J., Downing, J. A., Cotner, J. B., Loiselle, S. A., Striegl, R. G., Ballatore, T. J., Dillon, P., Finlay, K., Fortino, K., Knoll, L. B., Kortelainen, P. L., Kutser, T., Larsen, S., Laurion, I., Leech, D. M., McCallister, S. L., McKnight, D. M., Melack, J. M., Overholt, E., Porter, J. A., Prairie, Y., Renwick, W. H., Roland, F., Sherman, B. S., Schindler, D. W., Sobek, S., Tremblay, A., Vanni, M. J., Verschoor, A. M., von Wachenfeldt, E., and Weyhenmeyer, G. A..: Lakes and reservoirs as regulators of carbon cycling and climate, Limnol. Oceanogr., 54, 2298-2314, 2009.

Uehlinger, U.: Resistance and resilience of ecosystem metabolism in a flood-prone river system, Freshwater Biol., 45, 319-332, 2000.

Ulseth, A. J.: Sources, fates, and export of organic carbon in the Colorado River Basin, PhD Dissertation, University of Wyoming, Laramie, Wyoming, USA, 2012.

Vannote, R. L., Minshall, G. W., Cummins, K. W., Seell, J. R., and Cushing, C. E.: The river continuum concept, Can. J. Fish. Aq. Sci., 37, 130-137, 1980.

Vörösmarty, C. J., Sharma, K. P., Fekete, B. M., Copeland, A. H., Holden, J., Marble, J., and Lough, J. A.: The storage and aging of continental runoff in large reservoir systems of the world, Ambio, 26, 210-219, 1997.

Ward, J. V. and Stanford, J. A.: The serial discontinuity concept of lotic ecosystems, Dynamics of Lotic Ecosystems, edited by: Fontaine, T. D. and Bartell, S. M., Ann Arbor Science, Ann Arbor, Michigan, USA, 29-42, 1983.

Webster, J. R., Benfield, E. F., and Cairns, J.: Model predictions of effects of impoundment of particulate organic matter transport in a river system, in: The Ecology of Regulated Streams, edited by: Ward, J. V. and Stanford, J. A., Plenum Press, New York, USA, 339-364, 1979.

Weishaar, J. L., Aiken, G. R., Bergamaschi, B. A., Fram, M. S., Fujii, R., and Mopper, K.: Evaluation of specific ultraviolet absorbance as an indicator of chemical composition and reactivity 
of dissolved organic carbon, Environ. Sci. Technol., 37, 47024708, 2003.

Westerhoff, P. and Anning, D.: Concentrations and characteristics of organic carbon in surface water in Arizona: influence of urbanization, J. Hydrol., 236, 202-222, 2000.
Whittaker, R. H. and Likens, G. E.: Carbon in the biota, Carbon and the biosphere, Conf-720510, United States Atomic Energy Commission, edited by: Woodwell, G. M. and Pecan, E. V., Springfield, Virginia, USA, 281-302, 1973. 